\title{
Mechanisms of summertime upper Arctic Ocean warming and the effect on sea ice melt
}

\author{
Michael Steele, ${ }^{1}$ Jinlun Zhang, ${ }^{1}$ and Wendy Ermold ${ }^{1}$ \\ Received 1 October 2009; revised 15 July 2010; accepted 10 August 2010; published 6 November 2010.
}

[1] In this study, we use a numerical sea-ice-ocean model to examine what causes

summertime upper ocean warming and sea ice melt during the 21 st century in the Arctic

Ocean. Our first question is, "What causes the ocean to warm in the Pacific Sector during the summer"? We find that about $80 \%$ of total heating over this region comes from ocean surface heat flux, with the remaining $20 \%$ originating in ocean lateral heat flux convergence. The latter occurs mostly within a few hundred kilometers of the northwest Alaskan coast. In the summer of 2007, the ocean gained just over twice the amount of heat it did over the average of the previous 7 years. Our second question is, "What causes sea ice to melt in the Pacific Sector during summer"? Our analysis shows that top melt dominates total melt early in the summer, while bottom melt (and in particular, bottom melt due to ocean heat transport) dominates later in the summer as atmospheric heating declines. Bottom melt rates in summer 2007 were $34 \%$ higher relative to the previous 7 year average. The modeled partition of top versus bottom melt closely matches observed melt rates obtained by a drifting buoy. Bottom melting contributes about $2 / 3$ of total volume melt but is geographically confined to the Marginal Ice Zone, while top melting contributes a lesser 1/3 of volume melt but occurs over a much broader area of the ice pack.

Citation: Steele, M., J. Zhang, and W. Ermold (2010), Mechanisms of summertime upper Arctic Ocean warming and the effect on sea ice melt, J. Geophys. Res., 115, C11004, doi:10.1029/2009JC005849.

\section{Introduction}

[2] The Arctic Ocean gains heat via warm northward flowing currents from the Atlantic Ocean [Gerdes et al., 2003; Polyakov et al., 2007; Schauer et al., 2002] and from the Pacific Ocean [e.g., Shimada et al., 2006; Woodgate et al., 2006]. These currents have warmed in recent years [Polyakov et al., 2007; Woodgate et al., 2006], and may be contributing to sea ice melt [Polyakov et al., 2010; Shimada et al., 2006; Steele and Boyd, 1998]. However, in the central Arctic Ocean these waters reside within or below a strong pycnocline that tends to suppress upward heat flux [Aagaard et al., 1981; Polyakov et al., 2010; Steele and Boyd, 1998].

[3] The surface layers of the Arctic Ocean have also been warming. Figure 1 presents an update from Figure 3 of Steele et al. [2008], showing satellite-derived September mean sea surface temperature (SST) anomalies from 2007 and 2008, relative to the mean over 1982-2006. The summer of 2007 saw unprecedented sea ice retreat, notably in the Beaufort, Chukchi, East Siberian and Laptev Seas and northward into the deep Arctic Ocean basin, an area we will term here the "Pacific Sector." This retreat was forced by a combination of anomalous atmospheric conditions acting on an increasingly thin sea ice cover [Comiso et al., 2008; Lindsay et al., 2009;

\footnotetext{
${ }^{1}$ Polar Science Center, Applied Physics Laboratory, University of Washington, Seattle, Washington, USA.

Copyright 2010 by the American Geophysical Union. 0148-0227/10/2009JC005849
}

Nghiem et al., 2007; Zhang et al., 2008b]. This allowed an unprecedented amount of solar energy to enter the ocean, an amount sufficient to explain the observed bottom melting at a drifting ice buoy in the Beaufort Sea [Perovich et al., 2008]. Summer ice retreat in 2008 was the second highest in the historical satellite record. However, except north of Alaska, this retreat occurred relatively late in the summer, which may have limited the time over which solar heating could have warmed the ocean surface.

[4] So what are the relative roles of solar heating and ocean advection in the summer warming of the surface layers of the Arctic Ocean? The first goal of this study is to better understand this partition. The second goal is to quantify the role of this ocean heat on sea ice melt. Our focus will be on changes over the Pacific Sector in the 21st century, and especially on the summer of 2007. The tool we will use is a coupled sea-ice-ocean numerical model, with which we can make complete and closed budgets of ocean heat and sea ice volume. Section 2 discusses the model used in this study, and presents a validation against observations of upper ocean temperatures. This is followed by section 3 on the ocean heat budget, and then by section 4 on the ice melt budget. We conclude with a summary and discussion (section 5).

\section{Methods}

[5] Our main analysis tool is model output from a coupled sea-ice-ocean model of the arctic seas, the pan-Arctic iceocean modeling and assimilation system (PIOMAS) of Zhang and Rothrock [2003]. The ocean component is based on the 


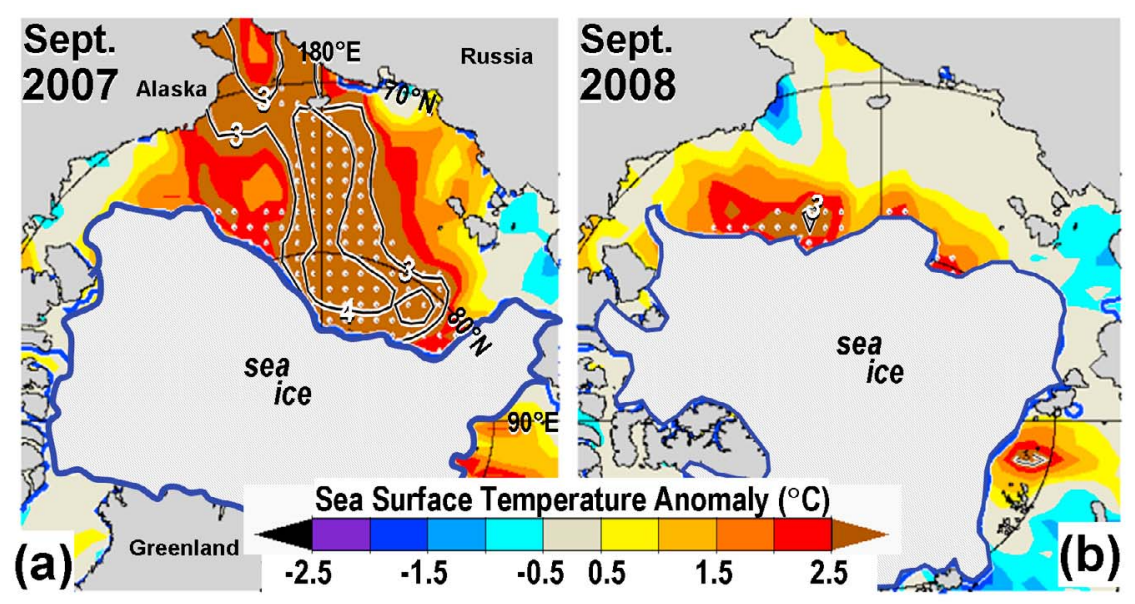

Figure 1. Sea surface temperature anomalies from the Advanced Very High Resolution Radiometer (AVHRR) satellite [Reynolds et al., 2002] for (a) September 2007 and (b) September 2008, both relative to the September $1982-2006$ mean. Contours are added for $3^{\circ} \mathrm{C}$ and $4^{\circ} \mathrm{C}$. White dots indicate values greater than 3 standard deviations above the mean. Also shown is the September mean sea ice extent from the National Centers for Environmental Prediction (ftp://polar.ncep.noaa.gov/pub/cdas/). A temperature of $-1.8^{\circ} \mathrm{C}$ is assumed under sea ice.

Parallel Ocean Program (POP) ocean model [e.g., Smith et al., 1992], which is coupled to a multicategory thickness and enthalpy distribution (TED) sea ice model [Hibler, 1980; Zhang and Rothrock, 2001]. The POP model is a B grid Bryan-Cox-Semtner type ocean model [Bryan, 1969; Semtner, 1976] with an implicit free surface formulation of the barotropic mode and model adaptation to parallel computing. The TED sea ice model has 12 categories each for ice thickness, ice enthalpy, and snow depth [Zhang et al., 2000]. Mean horizontal resolution of both ice and ocean models is about $22 \mathrm{~km}$, with higher resolution near Greenland where the North Pole is displaced by a linear orthogonal transformation. Resolution across Bering Strait is three grid cells for scalars (temperature and salinity) and two for velocity, which provides realistic volume transport [Zhang et al., 2008a] although higher resolution would probably enhance the accuracy of near-coastal flows and eddies. The ocean model's vertical dimension has 30 levels of varying thicknesses, starting with six $5 \mathrm{~m}$ thick levels at the surface and 13 levels in the upper $100 \mathrm{~m}$. Ocean mixing follows the $\mathrm{K}$ profile parameterization, as discussed by Zhang and Steele [2007], while ice-ocean heat flux parameterizations were discussed by Hibler [1980] and Hibler and Bryan [1987]. Open boundary conditions for sea surface height and ocean velocity, temperature, and salinity are specified along the model's southern boundary at $43^{\circ} \mathrm{N}$ from a global version of the model [Zhang, 2005]. Daily NCEP/NCAR reanalysis data are used as atmospheric forcing, i.e., $10 \mathrm{~m}$ surface winds, $2 \mathrm{~m}$ surface air temperature (SAT), specific humidity, precipitation, evaporation, downwelling longwave radiation, sea level pressure, and cloud fraction. Cloud fraction and SAT are used to calculate downwelling shortwave radiation following Parkinson and Washington [1979]. No shortwave radiation is allowed to penetrate through snow on sea ice, but some is allowed to penetrate through sea ice and below the ocean surface, with vertical attenuation coefficients of $1.5 \mathrm{~m}^{-1}$ (for ice [Maykut and Untersteiner, 1971]) and $0.10 \mathrm{~m}^{-1}$ (for ocean [Walsh et al., 2005]). Snow albedo is set at $0.80(0.75$ if melting), sea ice albedo is 0.70 ( 0.66 if melting), and ocean albedo is 0.10 [Maykut, 1982]. Climatological river discharge (i.e., no interannual variability) is provided as in the work of Hibler and Bryan [1987]. The model has the capability to assimilate ice concentration and ocean sea surface temperature observations through a nudging algorithm, but this function is not implemented in this study.

[6] The model was initially forced with repeated 1948 NCEP/NCAR fields for 30 years to equilibrate toward conditions during this year, and then forced with atmospheric fields from 1948 to 2007. Initial sea ice was at rest, with thickness of $2.6 \mathrm{~m}$ where the 1 January 1948 surface air temperature was equal to or colder than $-20^{\circ} \mathrm{C}$. Initial ocean temperature and salinity were taken from the 1982 version of the World Ocean Atlas [Levitus, 1982], with no initial ocean motion. Model output is generally saved as monthly averages, although some "snapshot" fields are also saved to provide differences over a month.

[7] The model has been validated using sea ice concentration, sea ice thickness, sea ice motion, ocean hydrography, and ocean transports [Lindsay et al., 2009; Zhang et al., 2008a; Zhang and Steele, 2007]. For this study, we looked in particular at summertime upper ocean temperature profiles in the areas of greatest ice retreat north of Alaska and the Chukchi Sea. Validation data were from in situ temperature profiles collected as part of the Beaufort Gyre Exploration Project (BGEP) and the Shelf-Basin Interactions (SBI) project. Figure 2 shows a comparison of these profiles taken from observations and from the model. In this comparison, it is important to make sure that observed and modeled temperature profiles are either both in open water or both under the sea ice pack, given the potentially large sea surface temperature difference between these two regimes. Observed and modeled profiles will be in the same regime only when the modeled ice edge agrees with the observed ice edge. Figure 2a (inset) indicates that while this is generally the case, differences do exist. Thus the comparisons in Figure 2 are taken either well north of the ice edge (Figure 2a) or 


\section{Under Ice}

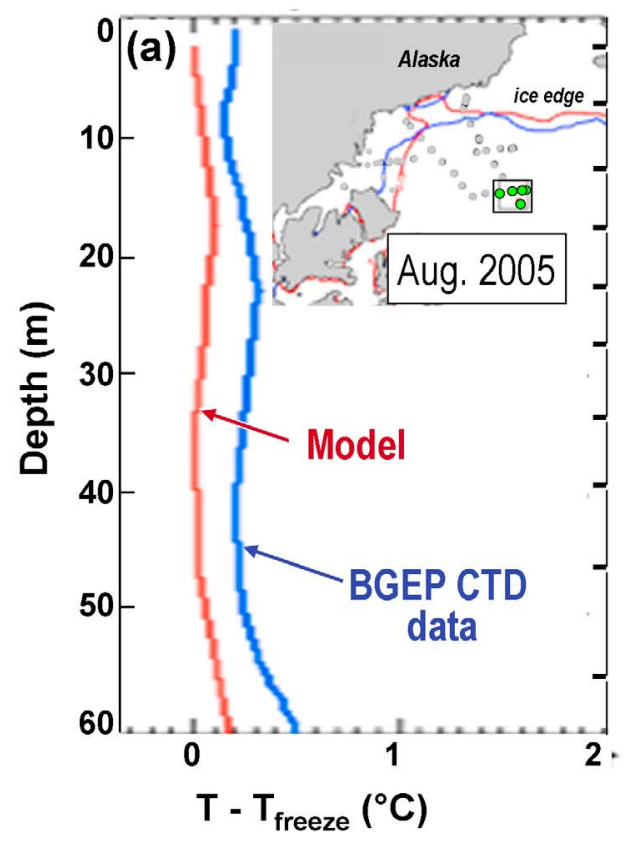

\section{Open Water}
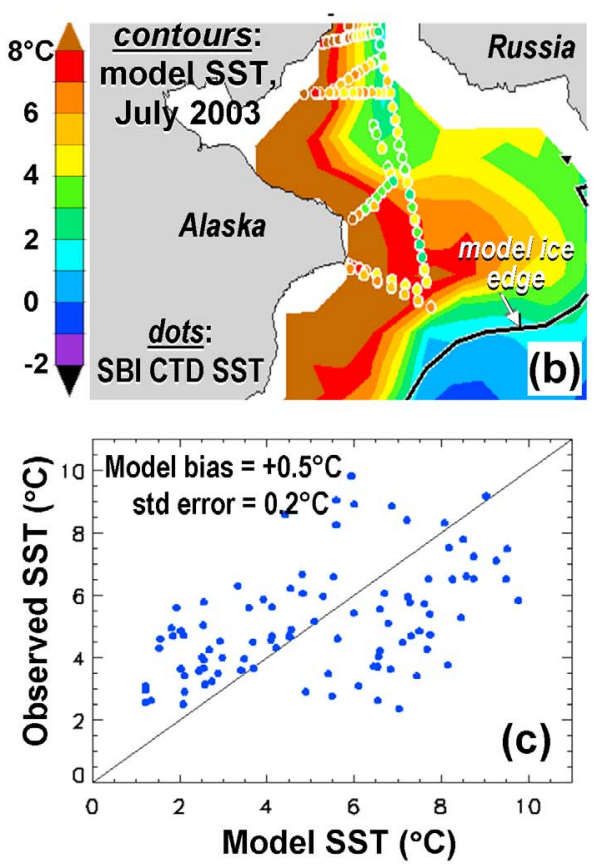

Figure 2. (a) Comparison of modeled (red) and observed (blue) 0-60 m depth ocean temperature profiles in the northernmost area of hydrographic (CTD) data collected in August 2005 (average of stations denoted by green dots in the small box in the inset) by the Beaufort Gyre Exploration Project (BGEP). (b) Comparison of modeled (contours) with observed (small colored dots) sea surface temperature (SST) data collected in July 2003 by the Shelf-Basin Interaction (SBI) project. SST is defined as the mean temperature over 7.5$12.5 \mathrm{~m}$ depth in both model and observations, in order to avoid the surface layer which is frequently undersampled and subject to high variance from ship and solar influences [Kara et al., 2000; de Boyer Montégut et al., 2004]. (c) Scatterplot of SSTs from Figure 2b, showing the bias and standard error of model output, relative to the observations.

well south of it (Figure 2b). Figure 2 indicates a modelobservation bias of order several tenths of a degree Celsius, with a similar standard error. The heat content bias corresponding to a $0.3^{\circ} \mathrm{C}$ temperature bias over $60 \mathrm{~m}$ is $78 \mathrm{MJ} \mathrm{m}^{-2}$.

\section{Upper Ocean Heat Budget}

[8] In this section, we examine the summertime heat budget of the Canadian Basin of the Arctic Ocean, i.e., the area where sea ice retreat has been most dramatic (Figure 1). We focus in particular on the maximum area of open water during summer 2007, as described below. In this study, we define "summer" as 1 June 1 to 15 September, which is the period during which sea ice is generally melting in this area [e.g., Belchansky et al., 2004] and thus open water area is increasing.

[9] We consider the upper 0-60 m layer, which with an attenuation coefficient of $0.1 \mathrm{~m}^{-1}$, absorbs $99.8 \%$ of the incoming solar energy. This layer lies just above the upper boundary of the summer Pacific Water layers [Steele et al., 2004] and spans the vertical extent of Bering Strait. The increase in heat content $\Delta \mathrm{H}$ over a square meter of ocean over a time interval $\Delta t$ can be written as

$$
\Delta \mathrm{H}=\Delta \mathrm{t}\left(\mathrm{F}_{\text {surf }}+\mathrm{F}_{\mathrm{adv}}+\mathrm{F}_{\mathrm{o}}\right),
$$

where the units of each term are $\mathrm{MJ} \mathrm{m}^{-2}$ and $\mathrm{F}_{\text {surf }}$ is the net surface heat flux, $F_{a d v}$ is the net advective heat flux, and $F_{o}$ represents the sum of all other ocean heat fluxes (discussed in more detail below). The fluxes have units of $\mathrm{W} \mathrm{m}^{-2}$. Each term in equation (1) is schematically illustrated in Figure 3. The net surface heat flux $F_{\text {surf }}$ is composed of the following three terms: (1) the net air-sea heat flux (i.e., the net turbulent plus radiative fluxes) including subsurface heating from penetrating solar radiative flux, (2) the heat flux from solar radiation penetrating through sea ice, and (3) the net iceocean heat flux. In the summer, the first two of these terms are generally heat sources to the ocean, while the last is a heat sink via melting. Thus, $\mathrm{F}_{\text {surf }}$ is the total heat flux at the surface of the ocean, whether that surface lies under air, ice, or a combination of both.

[10] The ocean advection term $F_{a d v}$ is actually the lateral heat flux convergence within the upper $60 \mathrm{~m}$ of the ocean. It arises from lateral gradients in ocean heat content, ocean velocity, or a combination of both. The term $F_{o}$ is calculated as a residual of the other terms in equation (1), and includes all other ocean heat transfers, i.e., from vertical heat flux convergence, from lateral plus vertical diffusion, and from vertical convection. This term includes heat flux into the upper $60 \mathrm{~m}$ from deeper warm ocean layers such as summer Pacific Water [e.g., Steele et al., 2004]. However, in the summer 


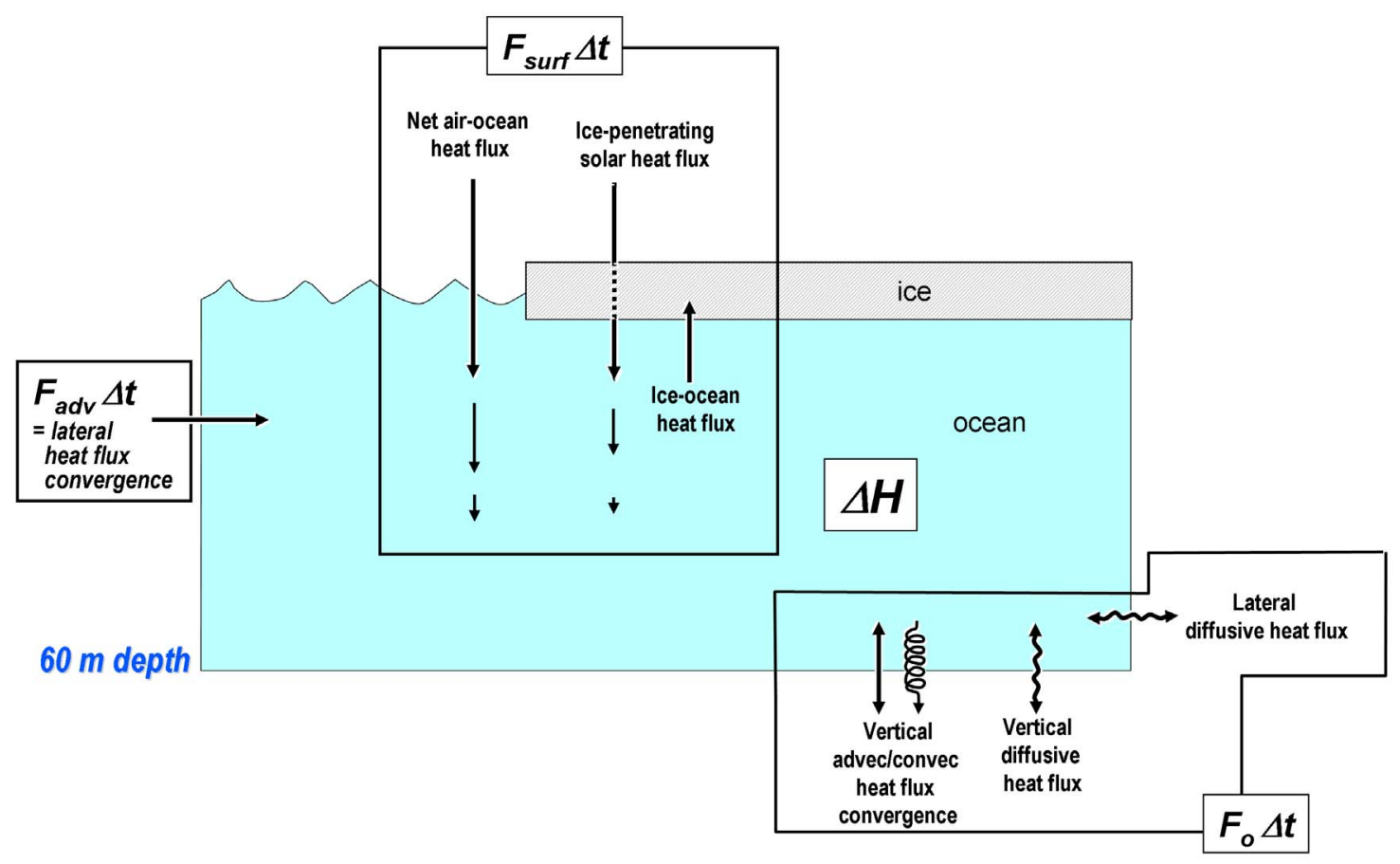

Figure 3. Schematic heat budget of the upper $60 \mathrm{~m}$ of the Arctic Ocean, with terms corresponding to those in equation (1).

strong upper ocean stratification tends to suppress vertical heat fluxes, so that $\mathrm{F}_{\mathrm{o}}$ is generally the smallest of the three on the right hand side of equation (1), as described below.

[11] Equation (1) describes heat content changes in the upper $60 \mathrm{~m}$ of the ocean over the entire summer, both before and after sea ice retreat. When sea ice is present in a grid cell, the uppermost ocean level remains at the freezing point even when there is net heat input. This heat is used to melt ice until it is completely gone. Below the uppermost level, advective and radiative heat fluxes can elevate the ocean above the freezing point, so that over the upper $60 \mathrm{~m}$ layer, $\Delta \mathrm{H}$ can increase even when ice is present. However, the bulk of summer ocean heating over this layer occurs after the ice retreats completely from a grid cell.

[12] Figure 4 shows maps of the three terms on the right hand side of equation (1). The net surface heating from $F_{\text {surf }}$ (Figures $4 \mathrm{a}$ and $4 \mathrm{~b}$ ) is generally large wherever there is open water. Although it covers a large area, its maximum amplitude is actually smaller than the more localized net advective heating $\mathrm{F}_{\mathrm{adv}}$. However, the $\mathrm{F}_{\mathrm{adv}}$ term is only large near Alaska (Figures $4 \mathrm{c}$ and $4 \mathrm{~d}$ ), where northward flowing currents warm the ocean via heat flux convergence. The extension of this heat source westward from Alaska into the Chukchi Sea might be exaggerated, given the model's overestimation of sea surface temperature in this region (Figure 2b). Finally, the $F_{o}$ term is generally small (Figures $4 \mathrm{e}$ and $4 \mathrm{f}$ ). In 2007, this term provides a small net heat sink that acts to partly counteract the $F_{\text {surf }}$ and $F_{\text {adv }}$ heat sources.

[13] In Figure 4b, the area of open water averaged over September 2007 (defined by Bering Strait, the coastlines, and the modeled mean September 2007 sea ice edge) is denoted by a light blue curve. We define this region as the "Pacific Sector" and perform all of our following budgets (for both 2007 and 2000-2006) over this area $=2.66 \times 10^{6} \mathrm{~km}^{2}$. For example, in Figure 4 we show the summertime heat input averaged over this region. In both time periods, $\mathrm{F}_{\text {surf }}$ is the largest term, $\mathrm{F}_{\mathrm{adv}}$ is next largest, and $\mathrm{F}_{\mathrm{o}}$ is the smallest. In $2007, \mathrm{~F}_{\text {surf }}$ was $250 \%$ larger than the 2000-2006 mean, while $\mathrm{F}_{\text {adv }}$ was $168 \%$ larger. While still the smallest term, the absolute magnitude of $F_{o}$ increased in 2007 but was negative, providing a heat sink as noted previously.

[14] Summer 2007 was notable for an early ice retreat, especially to the west of Amundsen Gulf, near Barrow, Alaska, and in the eastern East Siberian Sea and eastern Laptev Sea. This allowed atmospheric heating of the resulting open water areas, illustrated by large values of $F_{\text {surf }}$ in Figure 5. A broader, weaker area to the north of these open water areas is also evident in Figure 5, where atmospheric heating enters the ocean through the retreating, relatively low concentration ice cover.

[15] By late summer of 2007, the ice edge retreated northward, allowing wind forcing to act directly on the ocean to an unprecedented extent. Figure 6 illustrates the situation for the last 2 weeks of summer. In 2007, the ocean advective flux $\mathrm{F}_{\mathrm{adv}}$ shows strong heating near Barrow, Alaska and directly to the east along the coast. The maximum then turns northward and westward, presumably swept into the anticyclonic Beaufort High surface wind pattern (a winter phenomenon that persisted through the summer of 2007 to an unusual degree). The idea that retreating sea ice in this area might allow a more direct wind-ocean interaction (i.e., unmoderated by the sea ice cover), was first proposed by Shimada et al. [2006]. In fact, Shimada et al. proposed that this interaction might alter the direction of warm ocean currents, steering them more directly toward the sea ice pack. They speculated that this might encourage more sea ice melting than in years past with a heavier sea ice cover. Comparison of Figures $6 \mathrm{a}$ and $6 \mathrm{~b}$ indicates that in late sum- 
summer $2000-2006$
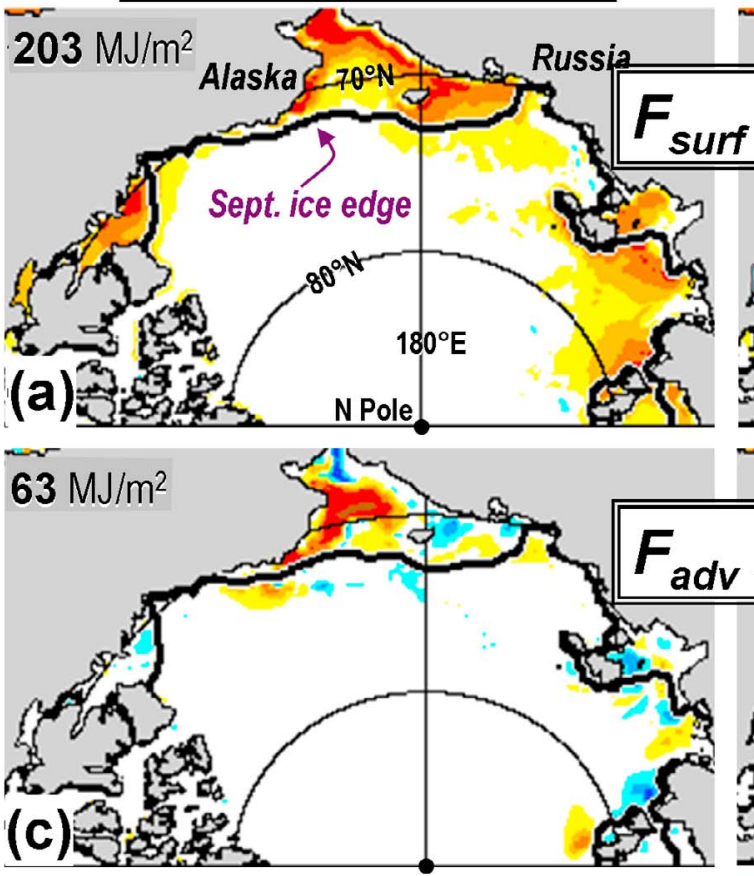

$\widetilde{4} \mathrm{MJ} / \mathrm{m}^{2}$

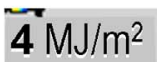

\section{summer 2007}

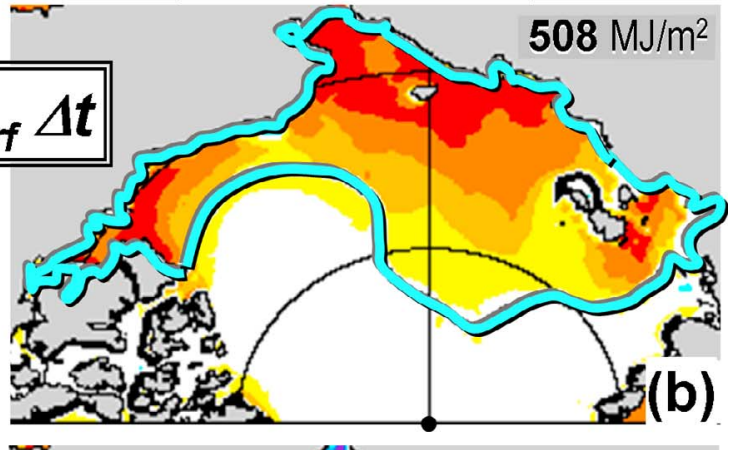

$106 \mathrm{MJ} / \mathrm{m}^{2}$

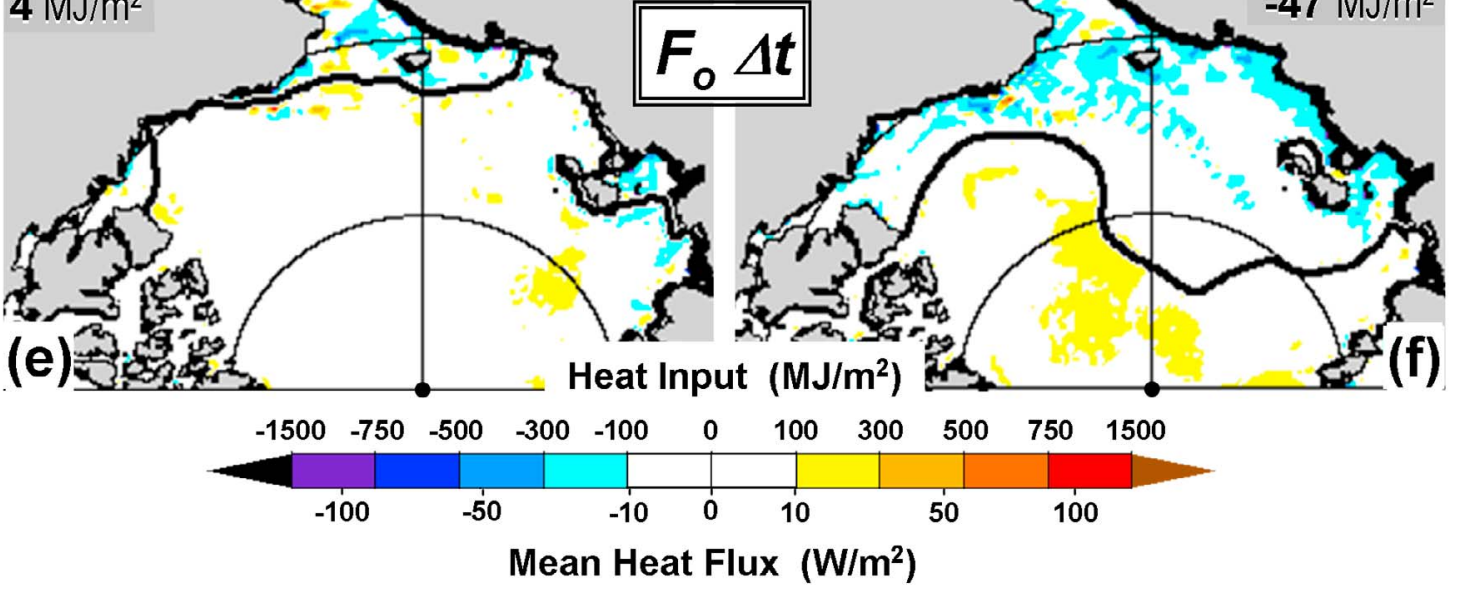

Figure 4. Heat input $\left(\mathrm{MJ} \mathrm{m}^{-2}\right)$ into the upper $60 \mathrm{~m}$ of the ocean over the summer, 1 June to 15 September (also presented as summer mean heat fluxes in units of $\mathrm{W} \mathrm{m}^{-2}$ ) averaged (a, c, and e) over 2000-2006 and (b, d, and f) over 2007. The net surface fluxes are $\mathrm{F}_{\text {surf }}$ (Figures $4 \mathrm{a}$ and $4 \mathrm{~b}$ ), the lateral heat flux convergence is $\mathrm{F}_{\text {adv }}$ (Figures $4 \mathrm{c}$ and $4 \mathrm{~d}$ ), and all other ocean heat fluxes are $\mathrm{F}_{\mathrm{o}}$ (Figures $4 \mathrm{e}$ and $4 \mathrm{f}$ ). Also shown is the modeled September mean ice edge averaged over 2000-2006 (Figures 4a, 4c, and 4e) and from 2007 (Figures $4 \mathrm{~b}, 4 \mathrm{~d}$, and 4f). The light blue curve in Figure $4 \mathrm{~b}$ denotes the "Pacific Sector" area used for averaging fluxes and budgets, e.g., the mean heat input over this fixed area is shown in the upper outer corner.

mer, the amplitude of $\mathrm{F}_{\mathrm{adv}}$ in this area is larger; however, it is not clear that the pathway of this warm current was appreciably altered. A similar conclusion might be reached for the summer average $F_{\text {adv }}$ seen in Figures $4 \mathrm{c}$ and $4 \mathrm{~d}$.

[16] To test this idea further, Figure 7 shows $0-60$ depthaveraged mean and anomalous ocean temperatures and velocities. Along the main pathway of Pacific water circulation (i.e., along the northwest Alaskan coast, then north and then west/northwest into the Beaufort Gyre anticyclone) the anomaly vectors are comparable in direction relative to the 2007 velocities. This indicates that the warm Pacific waters did not substantially change their direction of flow in summer 2007; rather, in this simulation they simply accelerated, bringing warmer water farther into the Beaufort Gyre.

[17] What was the regional mean heat budget over the entire Pacific Sector? Figure 8 shows a summary of the heat budget over this area (defined in Figure 4b), with all terms presented as the total amount of heat absorbed for June, July, August, the first half of September, and the summer total, in units of $10^{21} \mathrm{~J} \equiv 1 \mathrm{ZJ}$. Over the summer of 2007, the ocean gained $1.51 \mathrm{ZJ}$ over the Pacific Sector. Note that the potential bias in modeled upper ocean heat content was estimated in 


\section{July 2007}
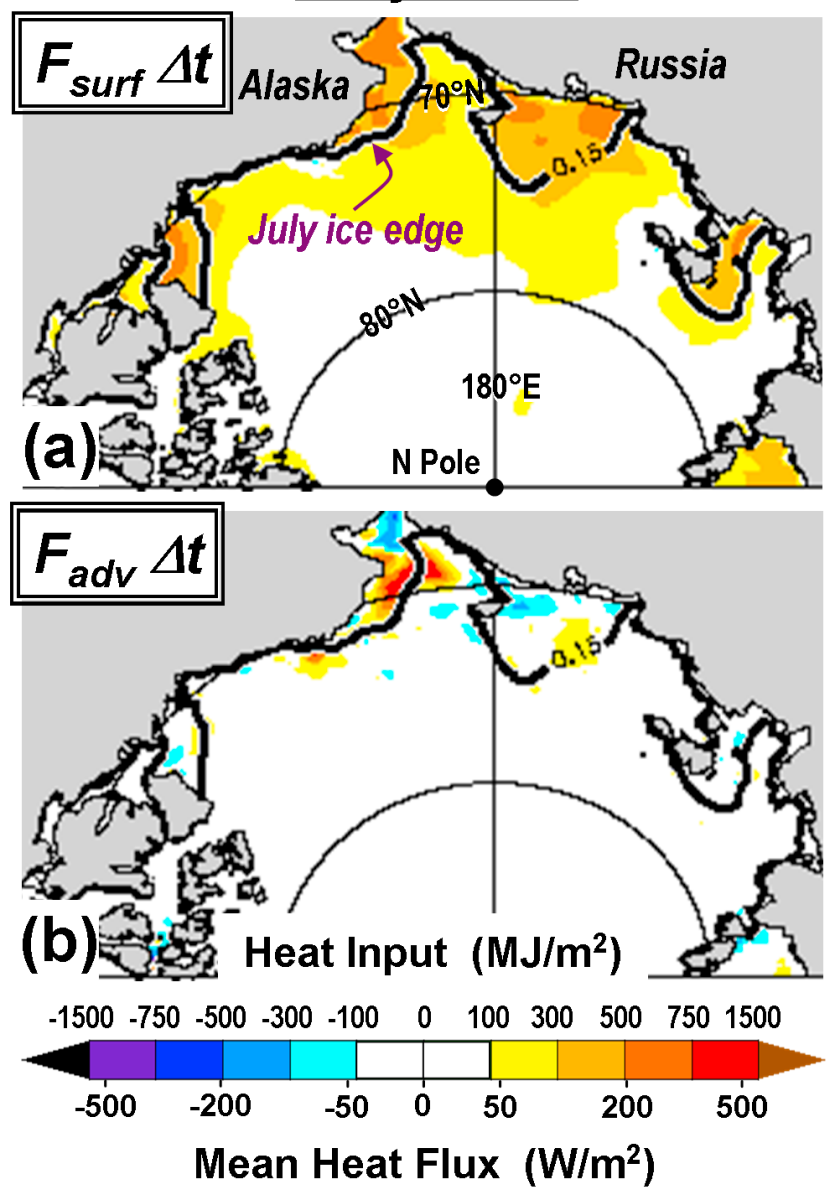

Figure 5. As in Figure 4 but for (a) $F_{\text {surf }} \Delta t$ and (b) $F_{a d v} \Delta t$ in July 2007 only. Also shown is the modeled July 2007 mean ice edge. section 1 as $78 \mathrm{MJ} \mathrm{m}^{-2}$, which equals $0.21 \mathrm{ZJ}$ over the Pacific Sector, or about $14 \%$ of the summer total. The net surface heat flux contributed $1.35 \mathrm{ZJ}$, ocean advection contributed $0.28 \mathrm{ZJ}$, and other ocean processes provided a heat sink of $-0.13 \mathrm{ZJ}$. Regional total ocean heat advection is calculated here as the sum over all grid cells of $F_{a d v}$, which by the divergence theorem is equal to the net flux across the lateral boundaries of the domain. There are two such boundaries: Bering Strait and the September 2007 ice edge. The heat flux across the former is much larger than that across the latter, a reflection of cooling between these two fluxgates. The net flux across both boundaries in summer 2007 contributed $0.28 \mathrm{ZJ}$ of heat, as noted previously. The total heat input from Bering Strait over that summer is $0.29 \mathrm{ZJ}$ (calculated explicitly from model temperature and velocity at the Strait), or about $50-60 \%$ of the 2007 annual total observed by Woodgate et al. [2010]. This implies a net loss across the internal boundary (i.e., the September 2007 ice edge position) of $0.01 \mathrm{ZJ}$, calculated as a residual of the other terms.

[18] Thus the 2007 net summertime surface heating was $83 \%=1.35 /(1.35+0.28)$ of the total heat input to the upper $60 \mathrm{~m}$ of the Pacific Sector, while ocean advection contributed $17 \%=0.28 /(1.35+0.28)$. Maximum heating from both surface and advective terms occurred in July and August. Averaged over the years 2000-2006, net summertime surface heating was $77 \%=0.54 /(0.54+0.16)$ of the total heat input, while ocean advection contributed $23 \%=0.16 /(0.54+0.16)$. In summary, during the summer of 2007 the Pacific Sector of the Arctic Ocean experienced 250\% higher surface heating, $175 \%$ higher ocean advective heating, and $210 \%=$ $1.51 /(1.51+0.72)$ higher net ocean warming, relative to the mean summers of 2000-2006.

\section{Thermodynamic Ice Mass Balance}

[19] What was the effect of this summertime ocean heating on the sea ice mass balance? To answer this question, we first partition summertime ice thickness change $\Delta \mathrm{h}$ into the two standard thermodynamic terms: top melting $\Delta \mathrm{h}_{\text {top }}$ which is forced by atmosphere-ice heat flux, and bottom melting $\Delta \mathrm{h}_{\text {bot }}$ which is forced by ocean-ice heat flux. (In fact, "bottom melting" in this study refers to the combined effects of

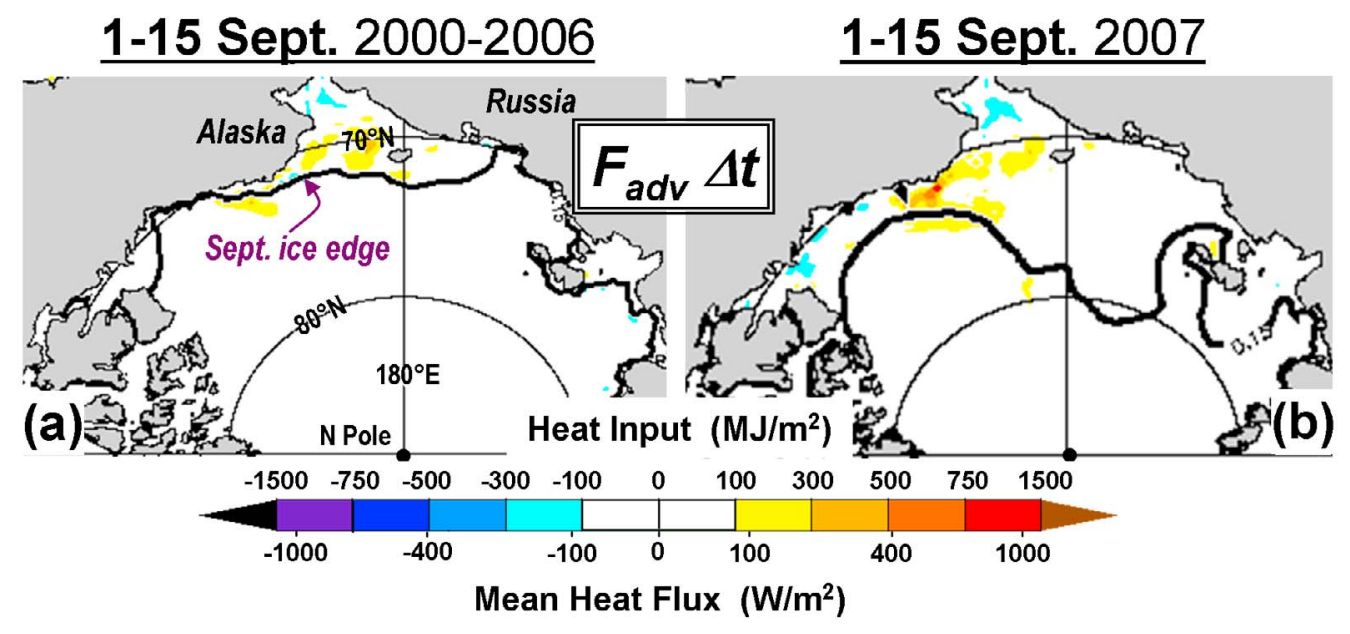

Figure 6. As in Figure 4 but for $F_{a d v} \Delta t$ averaged over 1-15 September (a) in 2000-2006 and (b) in 2007. Also shown is the modeled September 2007 mean ice edge. 


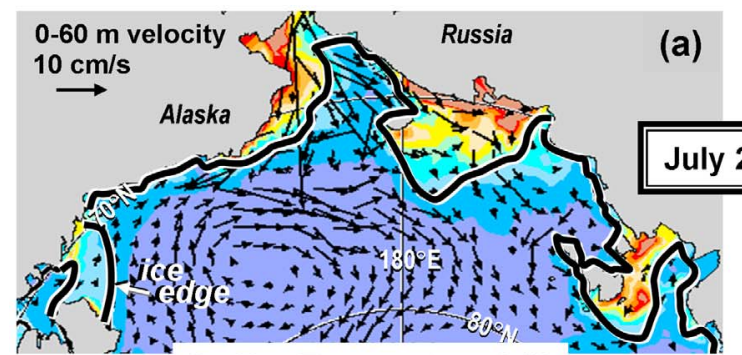

(a)

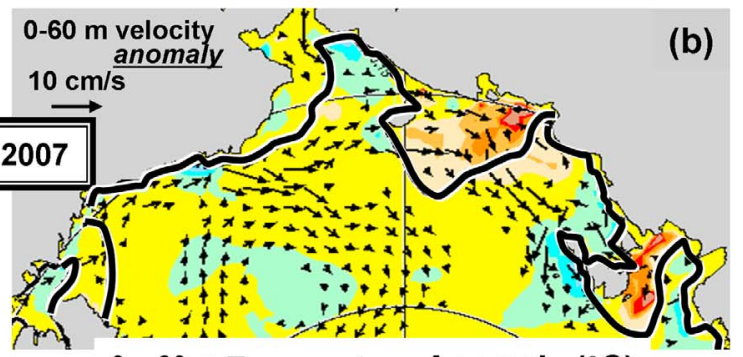

$0-60 \mathrm{~m}$ Temperature $\left({ }^{\circ} \mathrm{C}\right)$

$0-60 \mathrm{~m}$ Temperature Anomaly $\left({ }^{\circ} \mathrm{C}\right)$
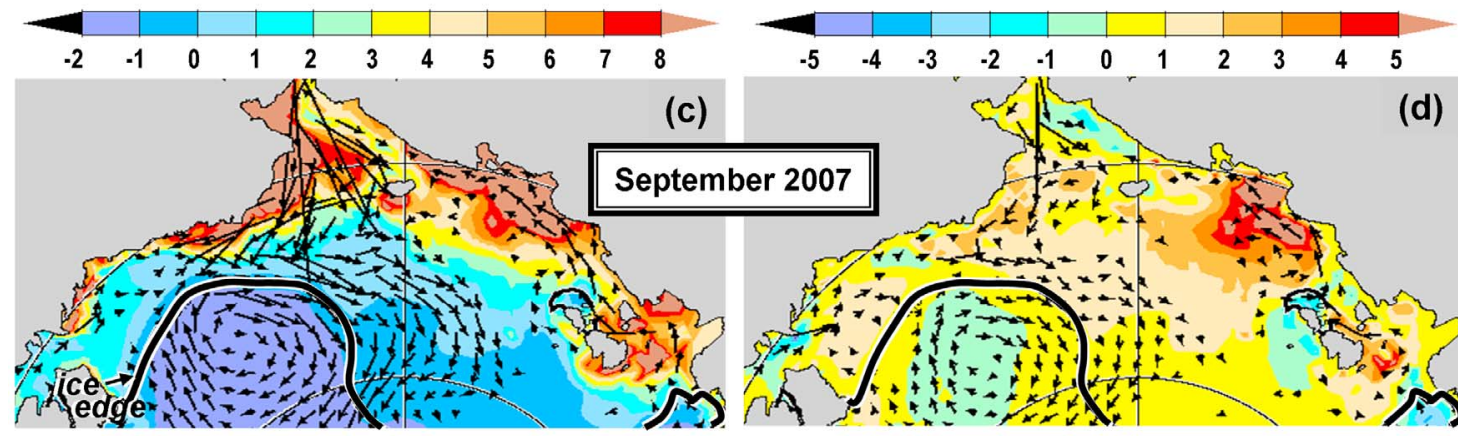

Figure 7. (a) July 2007 mean ocean temperature (contours) and mean ocean velocity (vectors), both averaged over the upper $60 \mathrm{~m}$. Also shown is the July 2007 modeled mean ice edge (black curve). (b) As in Figure 7a, for the ocean temperature and velocity anomalies relative to the July 2000-2006 mean. (c and d) The same information for September 2007 is shown. Velocity vectors less than or equal to $1 \mathrm{~cm} \mathrm{~s}^{-1}$ in magnitude are not plotted.

bottom and lateral melting, both forced by ice-ocean heat transfer.) We further partition the bottom melting into a local atmospheric contribution and a dynamical oceanic contribution, as described next.
[20] At the beginning of each time step in the model integration, an initial elevation above freezing is calculated when there is net positive heat flux into the uppermost grid cell. The heating from local atmospheric heat flux (net air-sea

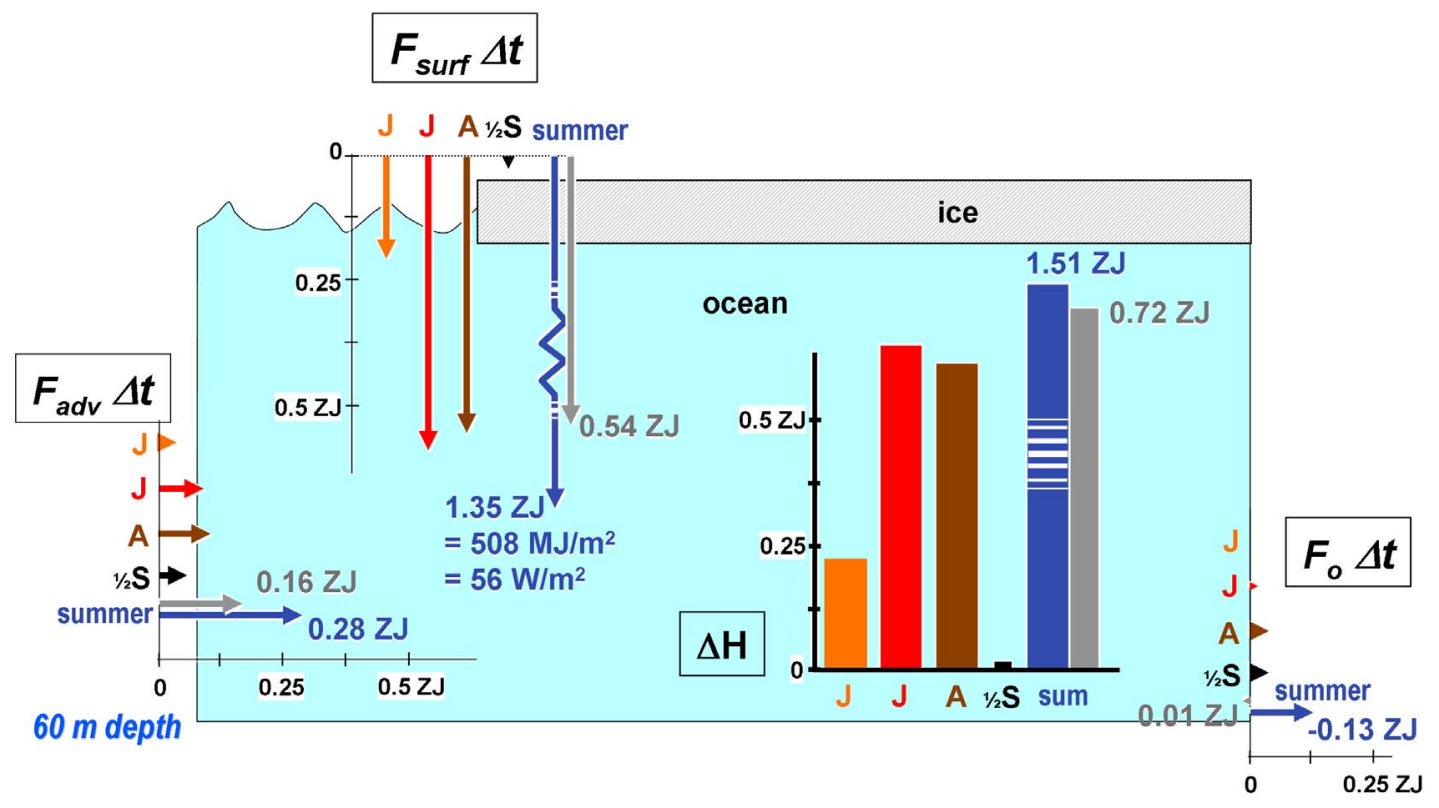

Figure 8. Total 2007 ocean heating $\Delta \mathrm{H}$ integrated over the area of the "Pacific Sector" (see Figure 4b) and its contributions from net ocean surface heat fluxes $\mathrm{F}_{\text {surf }} \Delta \mathrm{t}$, ocean advection $\mathrm{F}_{\text {adv }} \Delta \mathrm{t}$, and all other ocean fluxes $F_{o} \Delta t$, for the months of June (J), July (J), August (A), the first half of September (1/2S), and the summer total (sum). One $\mathrm{ZJ} \equiv 10^{21} \mathrm{~J}$. Also shown is the 2007 total surface heating over this area in units of $\mathrm{MJ} \mathrm{m}^{-2}$, and as a mean flux over the summer in units of $\mathrm{W} \mathrm{m}^{-2}$. Values in gray show summer totals for the period 2000-2006. 


\section{July 2007 Melt Budget}

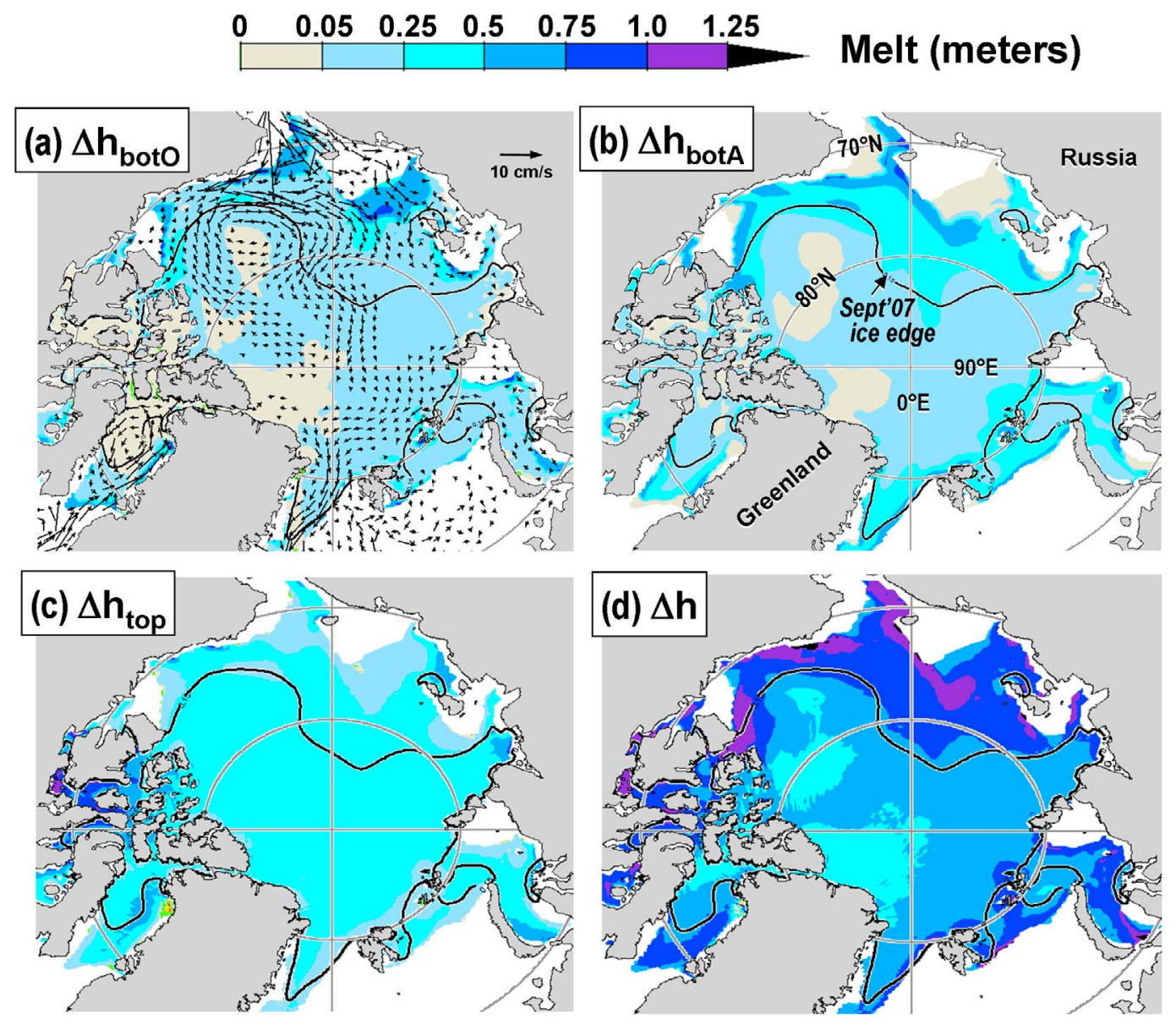

Figure 9. Thermodynamic sea ice thickness change (i.e., melt) in July 2007 from (a) bottom melting from ocean dynamics $\Delta \mathrm{h}_{\text {boto }}$, (b) bottom melting from local atmospheric heating of the ocean $\Delta \mathrm{h}_{\text {botA }}$, (c) top melting $\Delta \mathrm{h}_{\text {top }}$, and (d) the total thickness change $\Delta \mathrm{h}$. The modeled 2007 September mean sea ice edge is shown. White areas denote open water. Mean 0-60 m depth ocean currents for July 2007 (same as in Figure 7a) are shown in Figure 9a.

exchange including ice/snow penetrating solar radiation) is recorded separately from that induced by ocean dynamical process (i.e., relative sea-ice-ocean advection, diffusion, and convection). The total initial heat is then used for ice bottom melting in the grid cell, until all of this heat is used up or all of the ice melts. (In the latter case, if there is excess heat, then ocean warming will occur.) The total bottom melting $\Delta \mathrm{h}_{\text {bot }}$ is then partitioned between that forced by local atmospheric heating $\Delta \mathrm{h}_{\mathrm{botA}}$ and that forced by ocean dynamical processes $\Delta \mathrm{h}_{\text {botO }}$, in the same proportion as the initial heating.

[21] Thus in addition to the usual partition of top versus bottom melting, we can also combine $\Delta \mathrm{h}_{\text {top }}+\Delta \mathrm{h}_{\text {botA }}$ to determine the total ice melting from local atmospheric heat input. We can then contrast this with $\Delta \mathrm{h}_{\text {botO }}$, which is the ice melting forced only by dynamical ocean processes such as ocean currents (e.g., Figures 6 and 7) and upward heat transfer from subsurface warm layers such as those originating in the Pacific and Atlantic Oceans.

[22] Figure 9 shows the thermodynamic ice mass balance for July 2007. Total melting $\Delta \mathrm{h}$ is in general largest in southern areas of the ice pack. A broad area of high melt rates exists in the Pacific Sector, with values of nearly $1 \mathrm{~m}$ of melt over this month. Top melting $\Delta \mathrm{h}_{\text {top }}$ is relatively weak and uniform over the ice pack, in contrast to bottom melting, which reaches higher values but only near the ice edge. In particular, the dynamical ocean component of bottom melting $\Delta \mathrm{h}_{\text {botO }}$ is large to the west and north of each open water area in the Pacific Sector. This is consistent with Figure 5, which shows that these open water areas are warming in response to atmospheric heat input (and northward ocean current advection near Alaska). The ocean gains heat in these open water areas, and then the generally anticyclonic ocean circulation moves this heat west/northwestward under the adjacent sea ice, where the heat contributes to bottom melting. Figure 9a also shows that weak or southward ocean currents in the North Atlantic sector contribute to a negligible $\Delta \mathrm{h}_{\text {boto }}$ term in this area.

[23] Table 1 presents the thermodynamic ice volume losses in each month and over the entire summer, averaged over the Pacific Sector (defined in Figure 4b) and broken down into 
Table 1. Summertime Thermodynamic Ice Volume Loss, i.e., Melt, Over the Pacific Sector (Figure $4 \mathrm{~b}$ ) in Units of $10^{3} \mathrm{~km}^{3 \mathrm{a}}$

\begin{tabular}{|c|c|c|c|c|c|c|c|c|c|c|}
\hline & \multicolumn{2}{|c|}{$\Delta \mathrm{v}_{\text {botO }}$} & \multicolumn{2}{|c|}{$\Delta \mathrm{v}_{\text {botA }}$} & \multicolumn{2}{|c|}{$\Delta v_{\text {top }}$} & \multicolumn{2}{|c|}{$\Delta v$} & \multicolumn{2}{|c|}{$\Delta v_{\text {Bering }}$} \\
\hline & $2000-2006$ & 2007 & $2000-2006$ & 2007 & $2000-2006$ & 2007 & 2000-2006 & 2007 & 2000-2006 & 2007 \\
\hline June & 0.29 & 0.40 & 0.33 & 0.44 & 0.59 & 0.82 & 1.21 & 1.66 & 0.13 & 0.14 \\
\hline July & 0.58 & 0.72 & 0.58 & 0.70 & 0.70 & 0.58 & 1.86 & 2.00 & 0.25 & 0.32 \\
\hline August & 0.63 & 0.60 & 0.32 & 0.19 & 0.09 & 0.05 & 1.04 & 0.84 & 0.31 & 0.39 \\
\hline First half of September & 0.39 & 0.16 & 0.00 & 0.00 & 0.00 & 0.00 & 0.39 & 0.16 & 0.15 & 0.24 \\
\hline Summer & 1.89 & 1.88 & 1.23 & 1.34 & 1.37 & 1.44 & 4.49 & 4.66 & 0.84 & 1.09 \\
\hline
\end{tabular}

${ }^{\mathrm{a}}$ Given for bottom melt arising from ocean dynamics $\Delta \mathrm{v}_{\text {botO }}$, bottom melt arising from local ocean absorption of atmospheric heat $\Delta \mathrm{v}_{\text {botA }}$, top melt $\Delta \mathrm{v}_{\text {top }}$, and total melting $\Delta \mathrm{v}$. Also shown is the volume loss equivalent to the amount of heat entering the Arctic Ocean via Bering Strait $\Delta \mathrm{v}_{\text {Bering }}$, assuming an ice density of $900 \mathrm{~kg} \mathrm{~m}^{-3}$ and latent heat of fusion for sea ice of $3 \times 10^{5} \mathrm{~J} \mathrm{~kg}^{-1}$.

top melting and the two types of bottom melting discussed previously. Figure 10 shows the same information graphically. Integrated over the summer of 2007 , top melt $\Delta \mathrm{v}_{\text {top }}$ was $31 \%=1.44 / 4.66$ of the total volume melt, dynamical ocean bottom melting $\Delta \mathrm{v}_{\text {botO }}$ was $40 \%=1.88 / 4.66$ and local atmospheric bottom melting $\Delta \mathrm{v}_{\text {botA }}$ was $29 \%=1.34 / 4.66$. These percentages are similar for the 2000-2006 average. Thus while dynamical ocean bottom melting is the largest individual term, all three terms contribute significantly to the total. Dynamical ocean bottom melting is mostly geographically confined to areas just inside the ice edge (Figure 9), but it attains high amplitudes and thus contributes a significant amount $(40 \%)$ to the total melt budget. The rest $(60 \%)$ comes from local atmospheric heating, which melts ice from the top $\left(\Delta \mathrm{v}_{\text {top }}\right)$ and from the bottom $\left(\Delta \mathrm{v}_{\text {botA }}\right)$.

[24] Total thermodynamic ice volume loss is greatest in July, and thereafter declines as the amount of ice in the Pacific Sector declines. In 2007, ice melting was especially high in early summer, forced by both top and bottom melting increases. On the other hand, thermodynamic ice volume loss in the Pacific Sector was anomalously low in late summer 2007, as the ice volume in this area was small in response to the following two factors: (1) enhanced early summer melt and (2) southerly winds which exported ice toward the Eurasian Basin and through Fram Strait [Kwok, 2008; Lindsay et al., 2009; Nghiem et al., 2007; Zhang et al., 2008b]. The net result is that summer 2007 thermodynamic ice volume loss was only $4 \%=(4.66-4.49) / 4.49$ greater than the average over 2000-2006.

[25] Table 1 and Figure 10 also show the amount of ice that could be melted by the modeled heat flux that enters the Arctic Ocean through Bering Strait. This is generally smaller than $\Delta v_{\text {botO }}$, because other heat sources also contribute to this term (notably, lateral heat flux convergence from nearby open water cells that have been warmed by air-sea heating). Early in the summer (i.e., in June) heat flux from Bering Strait encounters sea ice just north of the Strait and thus contributes to substantial sea ice melt. By late summer (August/ September), ice melting is declining, even as the Bering Strait heat inflow increases. At this time, most of the heat inflow is used to warm the ocean and much less of it is directly melting ice. However, some of this heat might contribute to a suppression of fall ice growth, a subject beyond the scope of the present study.

[26] Figure 11 shows thermodynamic ice thickness changes (not ice thickness itself) from top melting and the two types of bottom melting, for the summer of 2007 and the mean over 2000-2006. In both periods, top and total bottom melt are nearly identical in June. However, as the summer progresses, top melting declines as solar energy input ebbs, while bottom melting (specifically, the dynamical ocean component $\Delta \mathrm{h}_{\text {botO }}$ ) increases as ocean warming increases

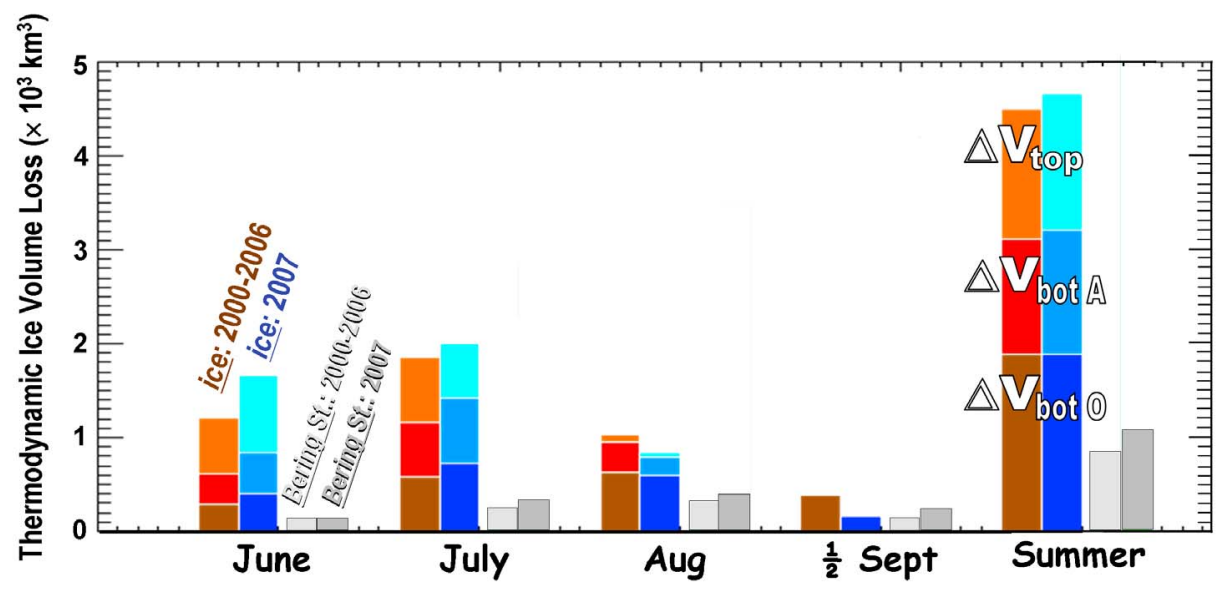

Figure 10. Summertime thermodynamic ice volume loss (i.e., melt) over the Pacific Sector (Figure 4b) in units of $10^{3} \mathrm{~km}^{3}$ for bottom melt arising from ocean dynamics $\Delta \mathrm{v}_{\text {botO }}$ (brown and dark blue bars), bottom melt arising from local ocean absorption of atmospheric heat $\Delta \mathrm{v}_{\mathrm{botA}}$ (red and medium blue bars), and top melt $\Delta v_{\text {top }}$ (orange and light blue bars). Also shown is the volume loss equivalent to the amount of heat entering the Arctic Ocean via Bering Strait $\Delta v_{\text {Bering }}$ (light and dark gray bars). 

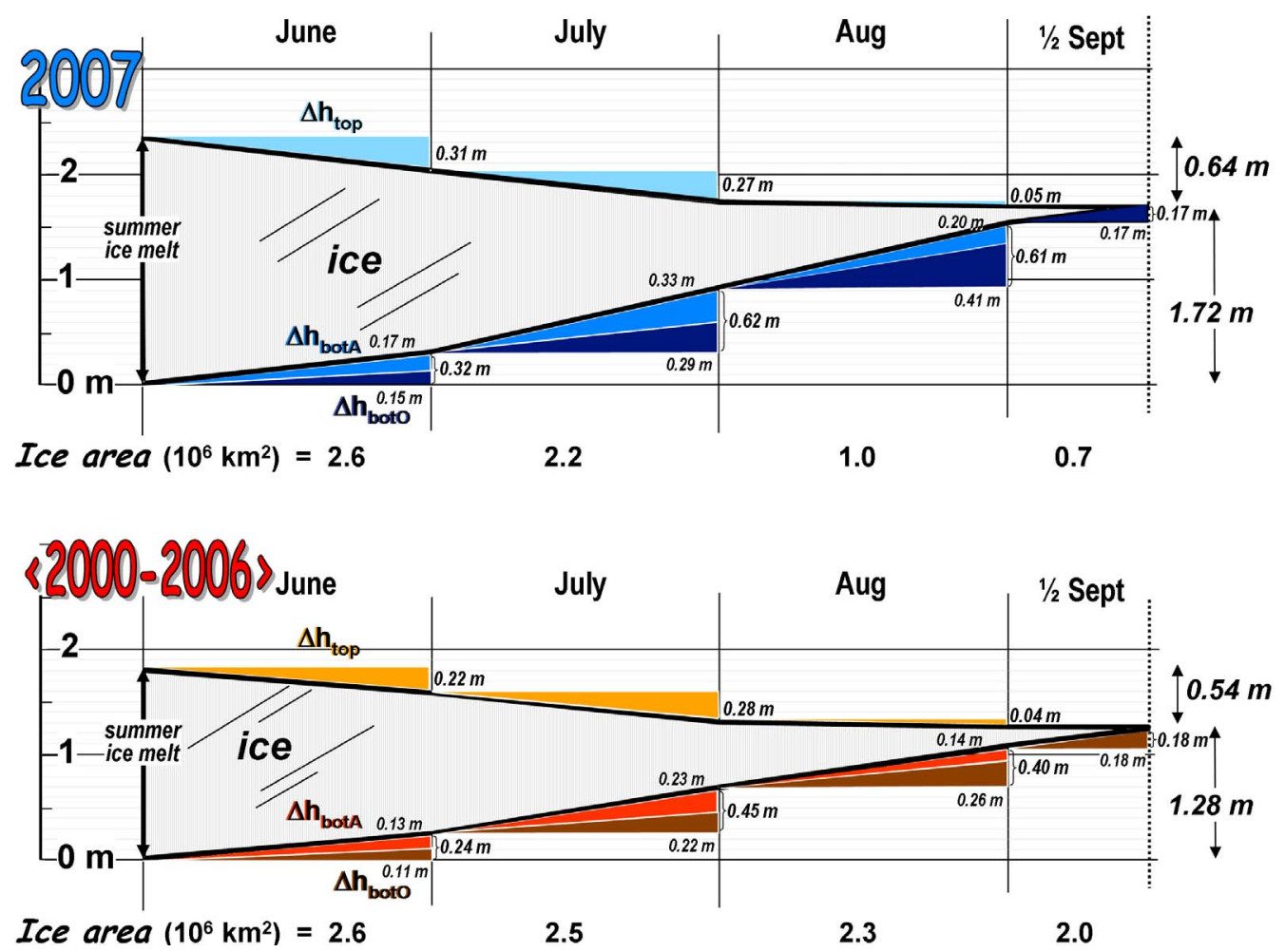

Figure 11. Summertime ice thickness change (in $\mathrm{m}$ ) over the Pacific Sector (top) in 2007 and (bottom) for the 2000-2006 mean, partitioned into top melt $\Delta \mathrm{h}_{\text {top }}$, bottom melt arising from local ocean absorption of atmospheric heat $\Delta \mathrm{h}_{\text {botA }}$, and bottom melt arising from ocean dynamics $\Delta \mathrm{h}_{\text {boto }}$. The total summer top and bottom melt is shown at the right. Also shown at the bottom is the ice-covered area in the Pacific Sector averaged over each month (or for September, averaged over the first 2 weeks). By the middle of September 2007 , ice area by definition was identically zero.

in July and August (Figure 8). By the end of summer, bottom melting has contributed over twice the ice thickness change of top melting. In 2007 , top melting increased by $19 \%=(0.64-$ $0.54) / 0.54$ over the $2000-2006$ average, but bottom melting increased even more, by $34 \%=(1.72-1.28) / 1.28$.

[27] Perovich et al. [2008] discuss observations taken by an ice mass balance buoy that drifted in the southern Beaufort Sea during the summer of 2007 . This buoy measured $0.65 \mathrm{~m}$ of top melting, which is nearly exactly the figure obtained by the model (Figure 11) for the average over the Pacific Sector. The observed total bottom melting was $2.10 \mathrm{~m}$, or $0.38 \mathrm{~m}$ meters more than the model estimate. The relatively good model-data correspondence is encouraging, but more data would be useful to determine if this is simply fortuitous.

\section{Summary and Discussion}

[28] Our model study indicates that most (77-83\%) of the summertime surface layer ocean warming in the Pacific Sector of the Arctic Ocean arises from local atmospheric heating (Figure 8), with a lesser input from ocean advection (i.e., Bering Strait inflow) that is confined mostly to within a few hundred kilometers of the northwest Alaskan coast. In the summer of 2007, the ocean gained a little over twice as much heat as it did averaged over the previous 7 years (Figure 8). A result was an ice bottom melt rate that was $34 \%$ greater than in this previous time period (Figure 11). However, the volume of ice melted by this warm water was only $4 \%$ greater in 2007 , a result partly of southerly winds which blew the ice away from the Pacific Sector. Summertime sea ice melting is forced by about $60 \%$ atmospheric fluxes (i.e., melting on the top surface of ice floes and also local warming of the ocean which then melts ice from the bottom and sides) and $40 \%$ from dynamical ocean processes (heat flux convergence, diffusion, and convection), as shown in Table 1 and Figure 10.

[29] The trigger for enhanced summer 2007 ocean warming was the early retreat of sea ice (Figures 9 and 10). This early ice retreat exposed the much lower-albedo ocean, which allowed enhanced atmospheric warming of the ocean, which in turn caused enhanced sea ice bottom melt. This process is commonly referred to as "ice-albedo feedback." Several papers discuss how to quantify this feedback [e.g., Graversen and Wang, 2009; Winton, 2006], for example by defining an amplification factor and then running twin experiments with fully coupled models, a control experiment and another with a "locked" climatological daily average albedo. However, this type of experiment is not straightforward to implement with our sea-ice-ocean model, since the atmospheric forcing is fixed.

[30] On the other hand, our results do demonstrate something about how sea ice melts. Figures $9 \mathrm{a}$ and $9 \mathrm{~b}$ show how ocean melting of sea ice is confined largely to the Marginal Ice Zone (MIZ), the region within a few hundred kilometers of the ice edge, where ice concentration is relatively low. As Figure 9 shows, this process is much weaker within the main ice pack. During the course of the spring and summer, the 
MIZ sweeps northward across the seasonal ice zone (i.e., between the end of winter and the end of summer ice edges), an area that has expanded in recent years. Although ocean melting is geographically constrained, its large amplitude contributes about $2 / 3$ of total volume melt in the Pacific Sector (Figure 10).

[31] Figure 9c shows how top melting, while small in amplitude, effects a much larger area than bottom melting. A process that in the future enhanced direct atmospheric melting of the ice top surface could thus be very efficient at reducing ice volume. An example might be increased atmospheric moisture, which would enhance downward longwave radiation, a process discussed by Graversen and Wang [2009] to explain "polar amplification" (i.e., why polar air temperatures warm more than in lower latitudes under global warming simulations.) In fact, enhanced top melting might lead to lower ice concentrations within the ice pack interior, which could enhance bottom melting in this region as well. Further work is needed to better understand these complex interactions.

[32] What happens to the heat accumulated in the ocean over the summer during the following fall? Much of it will quickly escape to the cooling atmosphere, delaying sea ice growth and affecting the overlying atmosphere itself with heat and moisture fluxes. Some may remain, however, for quite some time under the surface mixed layer [Jackson et al., 2010; Maykut and McPhee, 1995], retarding ice growth through the fall and even into the winter. This process could be substantially impacted by upper ocean stratification changes that we might expect during the transition to a more seasonal sea ice pack and an intensified hydrologic cycle [McPhee et al., 2009; Rawlins et al., 2010].

[33] Acknowledgments. We thank A. Schweiger and R. Lindsay for helpful discussions and the two anonymous reviewers for detailed comments. This work was supported by grants from the Arctic Section of the Office of Polar Programs at the National Science Foundation and from NASA's Cryosphere Research Program.

\section{References}

Aagaard, K., L. K. Coachman, and E. Carmack (1981), On the halocline of the Arctic Ocean, Deep Sea Res. Part A, 28, 529-545, doi:10.1016/01980149(81)90115-1.

Belchansky, G. I., et al. (2004), Duration of the Arctic Sea ice melt season: Regional and interannual variability, 1979-2001, J. Clim., 17, 67-80, doi:10.1175/1520-0442(2004)017<0067:DOTASI >2.0.CO;2.

Bryan, K. (1969), Climate and ocean circulation. Part 3. Ocean model, Mon. Weather Rev., 97, 806-827, doi:10.1175/1520-0493(1969) 097<0806:CATOC $>2.3 . \mathrm{CO} ; 2$.

Comiso, J. C., C. L. Parkinson, R. Gersten, and L. Stock (2008), Accelerated decline in the Arctic Sea ice cover, Geophys. Res. Lett., 35, L01703, doi:10.1029/2007GL031972.

de Boyer Montégut, C., G. Madec, A. S. Fischer, A. Lazar, and D. Iudicone (2004), Mixed layer depth over the global ocean: An examination of profile data and a profile-based climatology, J. Geophys. Res., 109, C12003, doi:10.1029/2004JC002378.

Gerdes, R., M. J. Karcher, F. Kauker, and U. Schauer (2003), Causes and development of repeated Arctic Ocean warming events, Geophys. Res. Lett., 30(19), 1980, doi:10.1029/2003GL018080.

Graversen, R. G., and M. H. Wang (2009), Polar amplification in a coupled climate model with locked albedo, Clim. Dyn., 33, 629-643, doi:10.1007/s00382-009-0535-6.

Hibler, W. D. (1980), Modeling a variable thickness sea ice cover, Mon. Weather Rev., 108, 1943-1973, doi:10.1175/1520-0493(1980) 108<1943:MAVTSI $>2.0 . \mathrm{CO} ; 2$.

Hibler, W. D., and K. Bryan (1987), A diagnostic ice ocean model, J. Phys. Oceanogr., 17, 987-1015, doi:10.1175/1520-0485(1987)017<0987: $\mathrm{ADIM}>2.0 . \mathrm{CO} ; 2$.
Jackson, J. M., E. C. Carmack, F. A. McLaughlin, S. E. Allen, and R. G. Ingram (2010), Identification, characterization and change of the nearsurface temperature maximum in the Canada Basin, 1993-2008, J. Geophys. Res., 115, C05021, doi:10.1029/2009JC005265.

Kara, A. B., P. A. Rochford, and H. E. Hurlburt (2000), An optimal definition for ocean mixed layer depth, J. Geophys. Res., 105, 16,80316,821, doi:10.1029/2000JC900072.

Kwok, R. (2008), Summer sea ice motion from the $18 \mathrm{GHz}$ channel of AMSR-E and the exchange of sea ice between the Pacific and Atlantic sectors, Geophys. Res. Lett., 35, L03504, doi:10.1029/2007GL032692.

Levitus, S. (1982), Climatological Atlas of the World Ocean, 173 pp., U.S. Dep. of Commer., Rockville, Md.

Lindsay, R. W., J. Zhang, A. Schweiger, M. Steele, and H. Stern (2009), Arctic sea ice retreat in 2007 follows thinning trend, J. Clim., 22, 165176, doi:10.1175/2008JCLI2521.1.

Maykut, G. A. (1982), Large-scale heat exchange and ice production in the central Arctic, J. Geophys. Res., 87, 7971-7984, doi:10.1029/ JC087iC10p07971.

Maykut, G. A., and M. G. McPhee (1995), Solar heating of the Arctic mixed layer, J. Geophys. Res., 100, 24,691-24,703, doi:10.1029/ 95JC02554.

Maykut, G. A., and N. Untersteiner (1971), Some results from a timedependent thermodynamic model of sea ice, J. Geophys. Res., 76, 1550-1575, doi:10.1029/JC076i006p01550.

McPhee, M. G., A. Proshutinsky, J. H. Morison, M. Steele, and M. B. Alkire (2009), Rapid change in freshwater content of the Arctic Ocean, Geophys. Res. Lett., 36, L10602, doi:10.1029/2009GL037525.

Nghiem, S. V., I. G. Rigor, D. K. Perovich, P. Clemente-Colón, J. W. Weatherly, and G. Neumann (2007), Rapid reduction of Arctic perennial sea ice, Geophys. Res. Lett., 34, L19504, doi:10.1029/2007GL031138.

Parkinson, C. L., and W. M. Washington (1979), A large-scale numericalmodel of sea ice, J. Geophys. Res., 84, 311-337, doi:10.1029/ JC084iC01p00311.

Perovich, D. K., J. A. Richter-Menge, K. F. Jones, and B. Light (2008), Sunlight, water, and ice: Extreme Arctic sea ice melt during the summer of 2007, Geophys. Res. Lett., 35, L11501, doi:10.1029/2008GL034007.

Polyakov, I., et al. (2007), Observational program tracks Arctic Ocean transition to a warmer state, Eos Trans. $A G U, 88,398-399$, doi:10.1029/ 2007EO400002.

Polyakov, I., et al. (2010), Arctic Ocean warming contributes to reduced polar ice cap, J. Phys. Oceanogr., doi:10.1175/2010JPO4339.1, in press.

Rawlins, M. A., et al. (2010), Analysis of the arctic system for freshwater cycle intensification: Observations and expectations, J. Clim., doi:10.1175/2010JCLI3421.1, in press.

Reynolds, R. W., N. A. Rayner, T. M. Smith, D. C. Stokes, and W. Wang (2002), An improved in situ and satellite SST analysis for climate, J. Clim., 15, 1609-1625, doi:10.1175/1520-0442(2002)015<1609: AIISAS $>2.0 . \mathrm{CO} ; 2$.

Schauer, U., B. Rudels, E. P. Jones, L. G. Anderson, R. D. Muench, G. Björk, J. H. Swift, V. Ivanov, and A.-M. Larsson (2002), Confluence and redistribution of Atlantic water in the Nansen, Amundsen and Makarov basins, Ann. Geophys., 20, 257-273, doi:10.5194/angeo-20-257-2002.

Semtner, A. J., Jr. (1976), Numerical simulation of Arctic Ocean circulation, J. Phys. Oceanogr., 6, 409-425, doi:10.1175/1520-0485(1976) 006<0409:NSOTAO $>2.0 . \mathrm{CO} ; 2$

Shimada, K., T. Kamoshida, M. Itoh, S. Nishino, E. Carmack, F. McLaughlin, S. Zimmermann, and A. Proshutinsky (2006), Pacific Ocean inflow: Influence on catastrophic reduction of sea ice cover in the Arctic Ocean, Geophys. Res. Lett., 33, L08605, doi:10.1029/2005GL025624.

Smith, R. D., J. K. Dukowicz, and R. C. Malone (1992), Parallel ocean general circulation modeling, Phys. D, 60, 38-61, doi:10.1016/01672789(92)90225-C

Steele, M., and T. Boyd (1998), Retreat of the cold halocline layer in the Arctic Ocean, J. Geophys. Res., 103, 10,419-10,435, doi:10.1029/ 98JC00580.

Steele, M., J. Morison, W. Ermold, I. Rigor, M. Ortmeyer, and K. Shimada (2004), Circulation of summer Pacific halocline water in the Arctic Ocean, J. Geophys. Res., 109, C02027, doi:10.1029/2003JC002009.

Steele, M., W. Ermold, and J. Zhang (2008), Arctic Ocean surface warming trends over the past 100 years, Geophys. Res. Lett., 35, L02614, doi:10.1029/2007GL031651.

Walsh, J. J., et al. (2005), A numerical model of seasonal primary production within the Chukchi/Beaufort Seas, Deep Sea Res. Part II, 52, 35413576, doi:10.1016/j.dsr2.2005.09.009.

Winton, M. (2006), Amplified Arctic climate change: What does surface albedo feedback have to do with it?, Geophys. Res. Lett., 33, L03701, doi:10.1029/2005GL025244.

Woodgate, R. A., K. Aagaard, and T. J. Weingartner (2006), Interannual changes in the Bering Strait fluxes of volume, heat and freshwater 
between 1991 and 2004, Geophys. Res. Lett., 33, L15609, doi:10.1029/ 2006GL026931.

Woodgate, R. A., T. Weingartner, and R. Lindsay (2010), The 2007 Bering Strait oceanic heat flux and anomalous Arctic sea-ice retreat, Geophys. Res. Lett., 37, L01602, doi:10.1029/2009GL041621.

Zhang, J. (2005), Warming of the arctic ice-ocean system is faster than the global average since the 1960s, Geophys. Res. Lett., 32, L19602, doi:10.1029/2005GL024216.

Zhang, J., and D. Rothrock (2001), A thickness and enthalpy distribution sea-ice model, J. Phys. Oceanogr., 31, 2986-3001, doi:10.1175/15200485(2001)031<2986:ATAEDS>2.0.CO;2.

Zhang, J., and D. A. Rothrock (2003), Modeling global sea ice with a thickness and enthalpy distribution model in generalized curvilinear coordinates, Mon. Weather Rev., 131, 845-861, doi:10.1175/1520-0493 (2003) $131<0845$ :MGSIWA $>2.0 . \mathrm{CO} ; 2$.

Zhang, J., and M. Steele (2007), Effect of vertical mixing on the Atlantic Water layer circulation in the Arctic Ocean, J. Geophys. Res., 112, C04S04, doi:10.1029/2006JC003732.
Zhang, J., D. Rothrock, and M. Steele (2000), Recent changes in Arctic sea ice: The interplay between ice dynamics and thermodynamics, J. Clim., 13, 3099-3114, doi:10.1175/1520-0442(2000)013<3099:RCIASI $>2.0$. $\mathrm{CO} ; 2$.

Zhang, J., et al. (2008a), The role of Pacific water in the dramatic retreat of arctic sea ice during summer 2007, Chin. J. Polar Sci., 19, 93-107.

Zhang, J. L., R. Lindsay, M. Steele, and A. Schweiger (2008b), What drove the dramatic retreat of arctic sea ice during summer 2007?, Geophys. Res. Lett., 35, L11505, doi:10.1029/2008GL034005.

W. Ermold, M. Steele, and J. Zhang, Polar Science Center, Applied Physics Laboratory, University of Washington, 1013 NE 40th St., Seattle, WA 98105, USA. (mas@apl.washington.edu) 